\title{
IMPLEMENTASI DATA MINING MENGGUNAKAN METODE DESKRIPSI UNTUK MENGETAHUI POLA PENENTUAN PENERIMA BANTUAN SISWA MISKIN (BSM) DI SMP N 3 DOLOKSANGGUL
}

\author{
Rusli Purba', Nelly Astuti Hasibuan², Edizal Hatmi ${ }^{3}$ \\ 1,2Program Studi Teknologi Informatika STMIK Budi Darma,Medan, Indonesia \\ Email: ${ }^{1}$ purbarusli5@gmail.com
}

\begin{abstract}
Abstrak
Bantuan Siswa Miskin ini sangat membantu siswa memenuhi kebutuhan di dalam kegiatan belajar maupun dalam melengkapi siswa itu sendiri ini sangat mendukung dalam program pemerintahan yang harus belajar sembilan tahun (lebih bagus lagi sampai tingkat menengah atas), untuk membantu kelancaran Bantuan Siswa Miskin yang bersifat langsung kepada siswa dan ini tidak bertujuan untuk siswa yang berprestasi karena mempertimbangkan kondisi siswa. Untuk mengetahui pola penentuan siswa penerima bantuan siswa miskin dapat dilakukan dengan cara memanfaatkan data siswa dan data penerima bantuan siswa miskin. Pencarian pola penentuan siswa penerima bantuan siswa miskin diharapkan bisa menganalisa faktor-faktor yang sangat menpengaruhi pada penerima bantuan siswa miskin. Metode yang sesuai dengan permasalahan diatas dengan menggunakan Metode Deskripsi, Deskripsi adalah salah satu kegunaan data mining untuk menggali dan menggumpulkan data yang banyak. Metode deskripsi berguna untuk kateristik atau menggambarkan suatu kondisi, sejarah, objek.
\end{abstract}

Kata Kunci : Data Mining, Bantuan Siswa Miskin, Metode Deskripsi.

\begin{abstract}
Poor Student Assistance is very helpful for students to meet the needs in learning activities and in completing the students themselves is very supportive in government programs that have to study nine years (preferably up to the upper secondary level), to help smooth the Poor Student Assistance which is directly to students and this does not aim for students who excel because it considers the condition of students. To find out the pattern of determining poor students' assistance recipients can be done by utilizing student data and poor student aid recipient data. Searching for patterns of determining students who receive aid from poor students is expected to be able to analyze the factors that greatly affect the recipients of poor student assistance. The method in accordance with the above problems using the Description Method, Description is one of the uses of data mining to explore and collect a lot of data. The description method is useful for characterizing or describing a condition, history, object.
\end{abstract}

Keywords: Data Mining, Poor Student Assistance, Method Description.

\section{PENDAHULUAN}

Bantuan Siswa Miskin ini sangat membantu siswa memenuhi kebutuhan di dalam kegiatan belajar maupun dalam melengkapi siswa itu sendiri ini sangat mendukung dalam program pemerintahan yang harus belajar sembilan tahun (lebih bagus lagi sampai tingkat menengah atas), untuk membantu kelancaran Bantuan Siswa Miskin yang bersifat langsung ditujukan untuk siswa karena ini tidak bertujuan untuk siswa yang berprestasi karena mempertimbangkan kondisi siswa sedangkan jika berdasarkan prestasi itu merupakan beasiswa bukan bantuan siswa miskin. Penggumpulan data atau berkas-berkas bantuan siswa miskin di SMP N 3 masih menggunakan cara yang manual dalam memilih satu persatu yang berhak menerima bantuan siswa miskin (BSM), jika menggunakan cara ini maka waktu yang di butuhkan pasti akan sangat banyak dengan jumlah berkas yang sangat banyak bahkan sampai mencapai ratusan data siswa [1].

Untuk mengetahui pola penentuan siswa penerima bantuan siswa miskin dapat dilakukan dengan cara memanfaatkan data siswa dan data penerima bantuan siswa miskin. Pencarian pola penentuan siswa penerima bantuan siswa miskin diharapkan bisa menganalisa faktor-faktor yang sangat menpengaruhi pada penerima bantuan siswa miskin. Hal ini bisa membantu pihak sekolah menentukan lebih berhak menerima bantuan siswa miskin. Data mining merupakan serangkain proses untuk menggali nilai tambah dari suatu kumpulan data berupa pengetahuan yang selama ini tidak di ketahui secara manual, perlu diketahui bahwa data mining adalah usaha untuk memperoleh sedikit banyaknya data.

Metode yang sesuai dengan permasalahan diatas dengan menggunakan Metode Deskripsi. Deskripsi adalah beberapa kegunaan untuk data mining yang akan menggali dan menggumpulkan data yang banyak. . Metode deskripsi berguna untuk kateristik atau menggambarkan suatu kondisi, sejarah, objek. apakah semua orang atau yang berhubungan dengan atribut-atribut yang akan di jelaskan secara baik dengan data maupun dengan kata-kata. Deskripsi diharapkan dapat diterapkan dalam kasus penerimaan bantuan siswa miskin berdasarkan keadaan ekonomi dan bisa mendapat hasil lebih akurat dan bisa mendapat siswa yang lebih membutuhkan bantuan siswa miskin.

\section{TEORITIS}

\subsection{Data Mining}


Data mining sering disebut juga knowledge Discovery in Databases (KDD), yaitu dengan pengumpulan, pemakaian data historis untuk menemukan keteraturan, pola atau hubungan dalam set data berukuran besar. Keluaran data mining bisa dipakai untuk memperbaiki pengambilan keputusan dimasa depan Definisi lain diantaranya adalah pembelajaran berbasis induksi (induction-based learning) adalah proses pembentukan definisi-definisi konsep umum yang dilakukan dengan cara mengobservasi contoh-contoh spesifik dari konsep-konsep yang akan dipelajari. Data mining berisi pencarian atribut atau kriteria yang akan dimasukkan dalam database besar untuk memdapat hasil di masa mendatang. Pola-pola ini dikenali oleh perangkat tersebut yang bisa memberikan suatu alasan data yang berguna dan bermanfaat dan setelah itu dapat dipahami dengan benar [2].

\subsection{Metode Deskripsi}

Metode deskripsi adalah kegunaan untuk data mining bahwa mendapatkan atau mengkorek-korek data dan informasi yang banyak. Dua cara dalam menggambarkan data yaitu dengan menggunakan deskripsi grafis, deskripsi lokasi.

1. Deskripsi Grafis

Cara deskripsi grafis merupakan cara untuk menggambarkan data dalam bentuk grafik yang sesungguhnya. Gambar yang umum digunakan dalam mendeskripsikan grafik adalah diagram titik (dot diagram) dan histogram.

2. Meskipun deskripsi grafik telah menggambarkan karateristik data namun sifatnya masih kurang mudah dipahami dan masih kurang penyelesaiannya untuk dilakukan, oleh sebab itu masih dibutuhkan sebuah angka untuk dapat mewakili data yang telah di siapkan serta dapat memperolehnya dengan cara yang lebih mudah dari pada menggambar. Ada beberapa yang biasa digunakan untuk mengetahui lokasi tersebut

a. Rumus rata-rata berarti membuat menjadi rata dan nilai rata-rata tersebut berpendapat sebagai lokasi pusat, titik berat, atau keseimbangan data.

$$
\bar{X}=\frac{x_{1}+\cdots+x_{3}+x_{4}}{n}=\sum_{i=1}^{n} \frac{x_{i}}{n}
$$

Rumus diatas adalah rumus yang dipakai untuk menghitungan rata-rata. Berikut keterangannya:

$\mathrm{X}$ : rata-rata hitung

$x i$ : nilai sampe ke-i

$n$ :Jumlah sampel

b. Nilai tengah (Median), nilai penelitian secara asli bertempat ditengah-tengah. Langkah pertama tidak bisa lupa untuk mengurutkan semua data dari terkecil hingga yang besar. Apabila mempunyai nilai $n$ buah data $n$ adalah bilangan ganjil, maka letak nilai median dihitung menggunakan rumus dibawah. Apabila jumlah $n$ adalah bilangan genap maka median yang menghitung menggunakan rumus sebagai berikut:

$[(n+1) / 2]$ (apabila jumlah data ganjil)

$$
\text { Atau } \frac{\text { data } k e-\left[\frac{n}{2}\right]+\text { data } k e-\left[\left(\frac{n}{2}\right)+1\right]}{2} \quad \text { (apabila jumlah data genap) }
$$

Rumus adalah rumus yang digunakan untuk menghitung nilai tengah

$x$ : sampe ke-

$n$ :Jumlah seluruh.

\section{ANALISA DAN PEMBAHASAN}

Bantuan siswa miskin merupakan program yang direncanakan dan penyempurnaan program-program pendidikan yang telah ada, untuk klasifikasi khusus dengan siswa miskin. Program ini akan terus berkembang dan akan terus meningkat lagi dalam bentuk mengawasi dan mempermudah pelayanan agar tidak keluar dari sasaran. Verifikasi data terbaru, akurat dan langsung ke sasaran dengan meninjau bantuan yang telah diberikan, langsung pada yang menerima adalah tugas yang harus dilaksanakan instansi terkait program. Karena selama ini, jika ada yang mempertanyakan tentang BSM dan penerimanya, pihak sekolah yang membagikan dana kepada siswa, mereka selalu memberikan jawaban bahwa penerima dana BSM yang tercantum sudah valid hasil data yang keluar dari pemerintah.Prosedur dalam proses penerima bantuan siswa miskin dengan prosedur yang ditetapkan oleh pihak sekolah ialah yang pertama melengkapi syarat-syarat calon penerima bantuan siswa miskin dengan melengkapi berkas seperti SKM (surat tanda miskin) dari pemerintah setempat (kepala desa/ lurah), tanggungan orangtua, pekerjaan orangtua, penghasilan orangtua, penerima PIP, atau penerima KIP, status anak. Dari data-data akan di seleksi penerima bantuan siswa miskin, Jika data telah di seleksi maka akan ada daftar/ calon penerima bantuan siswa miskin kemudian daftar nama tersebut diserahkan kepada pihak yang memberikan bantuan siswa miskin tersebut yaitu dana bos maupun dari pemerintah. 


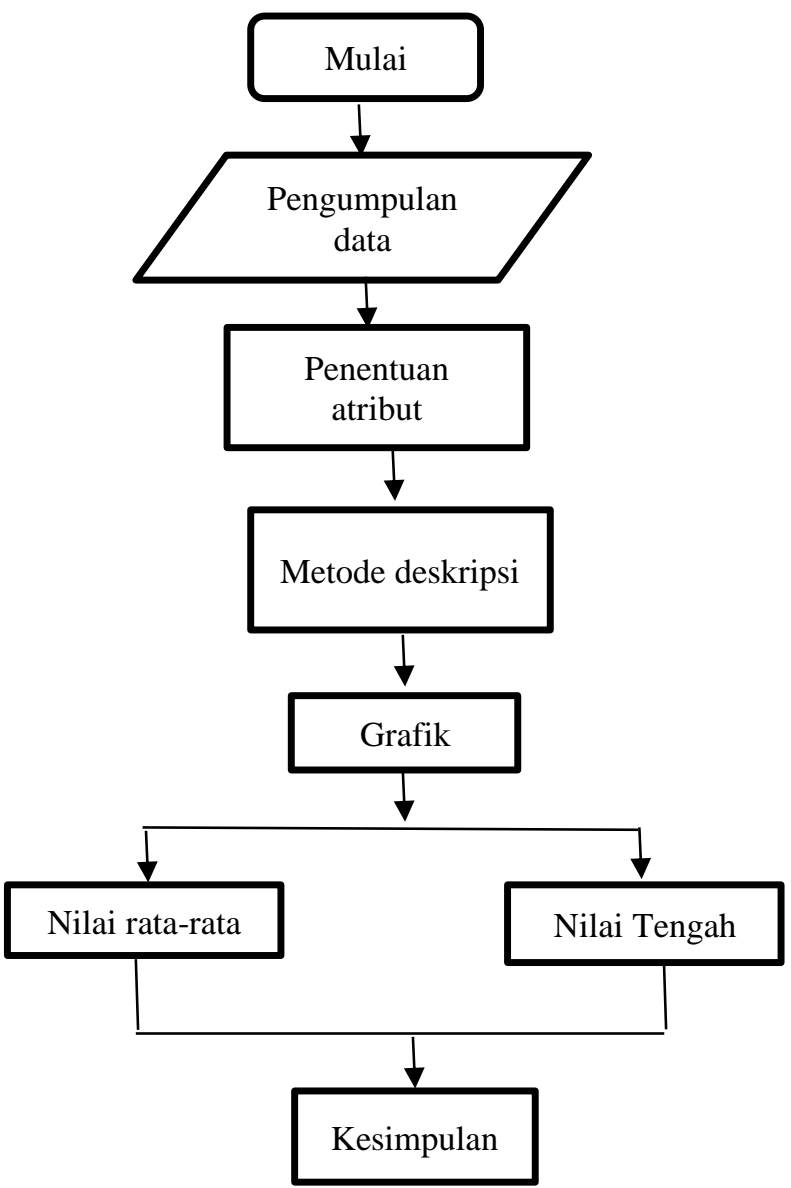

Gambar 1. Flowchart metode deskripsi

Berdasarkan gambar 1 di atas, diketahui bahwa pengumpulan data dapat menentukan banyaknya atribut untuk melakukan proses pengerjaan metode deskripsi yaitu dengan membuat grafik dari data-data yang telah dikumpulkan dan mendapat nilai rata-rata dan nilai tengah dan dapat menbuat hasil

\subsection{Proses pengumpulan data}

Selanjutnya akan dilakukan proses data calon penerima bantuan siswa miskin sebagai berikut:

Tabel 1. Data Hasil penerima bantuan siswa miskin

\begin{tabular}{clccccccc}
\hline \multirow{2}{*}{ No } & \multirow{2}{*}{ Nama } & \multicolumn{2}{c}{ Kriterian penerima calon bantuan siswa miskin (BSM) } & \multirow{2}{*}{ Keputusan } \\
\cline { 2 - 7 } & & $\mathrm{A}$ & $\mathrm{B}$ & $\mathrm{C}$ & $\mathrm{D}$ & $\mathrm{E}$ & $\mathrm{F}$ & \\
\hline 1 & Santi rina & $1-2$ & Petani & $>1 \mathrm{jt}$ & $\mathrm{T}$ & $\mathrm{T}$ & $\mathrm{L}$ & Layak \\
2 & Awi simamora & $>5$ & Petani & $>1 \mathrm{jt}$ & $\mathrm{T}$ & $\mathrm{T}$ & $\mathrm{L}$ & Layak \\
3 & Nesa sitohang & $3-5$ & Petani & $>2 \mathrm{jt}$ & $\mathrm{Y}$ & $\mathrm{T}$ & $\mathrm{L}$ & Layak \\
4 & Cindy sirait & $1-2$ & Buruh & $>1 \mathrm{jt}$ & $\mathrm{Y}$ & $\mathrm{T}$ & $\mathrm{L}$ & Tidak layak \\
5 & Mika nababan & $3-5$ & Petani & $>2 \mathrm{jt}$ & $\mathrm{T}$ & $\mathrm{T}$ & $\mathrm{L}$ & Tidak layak \\
6 & Desta simamora & $3-5$ & Pedagang & $>1 \mathrm{jt}$ & $\mathrm{T}$ & $\mathrm{T}$ & $\mathrm{L}$ & Layak \\
7 & Elsaria munthe & $>5$ & Buruh & $>1 \mathrm{jt}$ & $\mathrm{T}$ & $\mathrm{T}$ & $\mathrm{L}$ & Layak \\
8 & Leokardo silaban & $>5$ & Buruh & $>3 \mathrm{jt}$ & $\mathrm{Y}$ & $\mathrm{T}$ & $\mathrm{L}$ & Layak \\
9 & Josua purba & $3-5$ & Buruh & $>2 \mathrm{jt}$ & $\mathrm{T}$ & $\mathrm{T}$ & $\mathrm{L}$ & Layak \\
10 & Rafael silaban & $>5$ & Petani & $>2 \mathrm{jt}$ & $\mathrm{T}$ & $\mathrm{T}$ & $\mathrm{L}$ & Layak \\
\hline
\end{tabular}

Keterangan:

1. Nama merupakan nama dari siswa SMP N 3 Doloksanggul

2. Kriteria yang dibutuhkan dalam menentukan penerima bantuan siswa miskin:

a. A adalah kriteria jumlah tanggungan orangtua memiliki pilihan 1-2, 3-5, >5.

b. B adalah pekerjaan orangtua diantaranya: buruh, petani, pedagang kecil, karyawan swasta.

c. C adalah penghasilan orangtua memiliki pilihan sebagai berikut: $>1 \mathrm{jt},>2 \mathrm{jt},>3 \mathrm{jt}$.

d. D adalah penerima Program Indonesia Pintar (PIP) dengan pilihan ya atau tidak.

e. E adalah penerima KIP/ Kartu Indonesia Pintar dengan pilihan ya atau tidak.

f. F adalah status anak yang memiliki pilihan yaitu: yatim, piatu atau yatim piatu.

Adapun keterangan pilihan adalah sebagai berikut: 
1-2 : jika memiliki tanggungan kurang dari tiga

3-5 : jika memiliki tanggungan dari mulai tiga, empat atau lima keatas

$>5 \quad$ :jika memiliki tanggungan lebih dari lima keatas

$>1$ jt : jika penghasilan dibawah Rp.1.000.000

$>2 \mathrm{jt} \quad$ : yang berpenghasilan mulai dari Rp.2.000.000

$>3$ jt : jika penghasilan diatas dari Rp.3.000.000

$\mathrm{T} \quad$ : tidak

Y : ya

L : : keluarga lengkap

Yt : yatim

Yp : yatim piatu

$\mathrm{P} \quad$ : piatu

\subsection{Penerapan Metode Deskripsi}

berikut ini penyelesaian dari metode deskripsi dengan langkah-langkah Dibawah ini:

1. Deskripsi Grafis

Cara ini adalah langkah untuk mendeskripsikan data tersebut untuk membentuk gambar yang sebenarnya. Seperti pada grafik yang berdasarkan tabel 4.1 diatas adalah sebagai berikut:

a. Tanggungan

Kriteria dibagi berdasarkan banyaknya anak. Adapun tabel tanggungan adalah seperti di bawah ini:

Tabel 2 tanggungan

\begin{tabular}{llll}
\hline \multirow{2}{*}{ Tahun } & \multicolumn{3}{c}{ Frekuensi } \\
\cline { 2 - 4 } & $1-2$ & $3-5$ & $>5$ \\
\hline 2015 & 3 & 5 & 7 \\
2016 & 4 & 3 & 8 \\
2017 & 5 & 10 & 5 \\
\hline
\end{tabular}

Di bawah ini grafik dari tanggungan orangtua dari penerima bantuan siswa miskin adalah sebagai berikut:

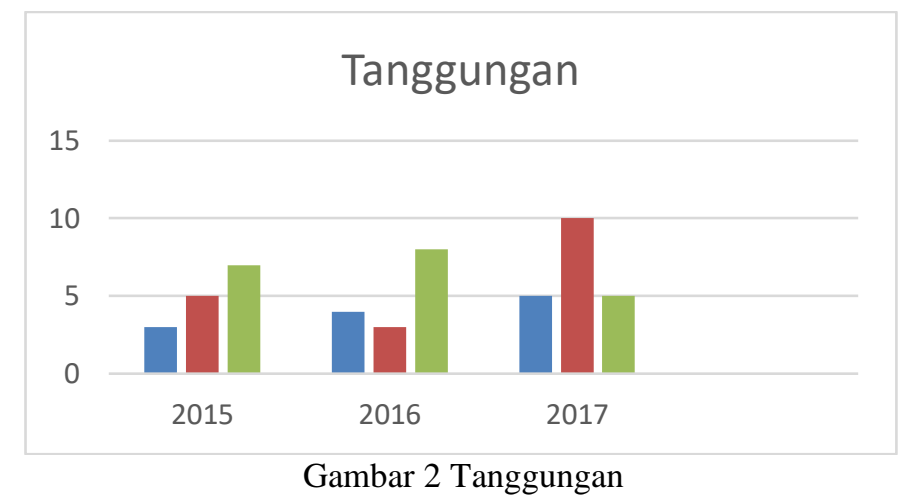

Berdasarkan hasil dari gambar 4.2 diatas dapat di simpulkan bahwa yang mendapatkan nilai tertinggi yaitu tanggungan $>5$

b. Pekerjaan

kriteria pekerjaan dibagi berdasarkan banyaknya pekerjaan. Adapun tabel pekerjaan merupakan seperti di bawah ini:

Tabel 3 pekerjaan

\begin{tabular}{ccccc}
\hline \multirow{2}{*}{ Tahun } & \multicolumn{4}{c}{ Frekuensi } \\
\cline { 2 - 5 } & Petani & Buruh & Pedagang & Karyawan Swasta \\
\hline 2015 & 7 & 5 & 3 & 0 \\
2016 & 7 & 3 & 4 & 1 \\
2017 & 10 & 5 & 4 & 1 \\
\hline
\end{tabular}

Dibawah ini adalah grafik dari pekerjaan orangtua dari penerima bantuan siswa miskin adalah sebagai berikut: 


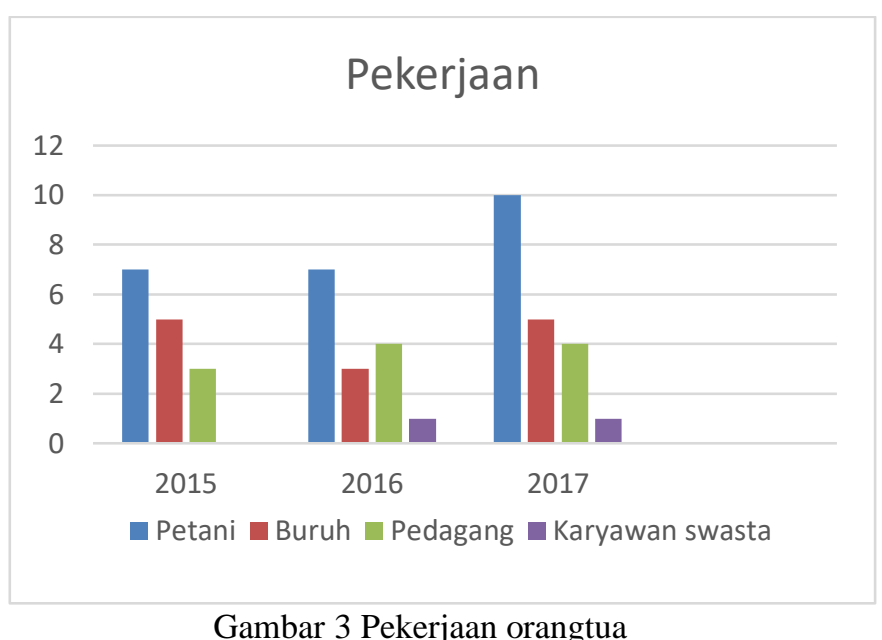

Berdasarkan hasil dari gambar 3 diatas dapat di ketahui bahwa yang mendapatkan nilai tertinggi yaitu pekerjaan petani

2. Deskripsi lokasi

Meskipun deskripsi grafik telah menggambarkan karateristik data namun sifatnya masih kurang mudah dipahami dan masih kurang penyelesaiannya untuk dilakukan, oleh sebab itu tetap dibutuhkan angka yang cukup mewakili data untuk memperoleh dengan cara yang lebih efisien pada gambar

a. Menampilkan nilai rata-rata

Untuk menghitung nilai rata-rata dengan membuat nilai menjadi rata dan nilai rata-rata tersebut dianggap sebagai lokasi pusat, titik pusat dan kesetimbangan data dengan rumus sebagai berikut:

$\bar{X}=\frac{x_{1}+\cdots+x_{3}+x_{4}}{n}=\sum_{i=1}^{n} \frac{x_{i}}{n}$

Berdasarkan data yang diperoleh dari pihak SMP Negeri 3 Doloksanggul, calon penerima bantuan siswa miskin.

Berikut ini hitungan dari tanggungan:
a. Tanggungan 1-2
$\frac{12}{3}=4$
b. Tanggungan 3-5
$\frac{18}{3}=6$
c. Tanggungan $>5$
$\frac{20}{3}=6,6$

Berdasarkan data yang telah di olah maka dari hasil perhitungan nilai rata-rata di atas maka dapat di buat kesimpulan untuk peluang paling besar dari seorang anak yang mendapatkan bantuan siswa miskin jika orangtua memiliki tanggungan $>5$ anak.

b. Menampilkan nilai Median

Sebelum mencari nilai tengah terlebih dahulu harus diketahui apakah jumlah data yang di observasi ganjil atau genap. Selain itu harus di urutkan berdasarkan data dengan banyak data terkecil hinga yang terbesar maka data letak median diperoleh dari perhitungan rumus $\{[(\mathrm{n} / 2)+((\mathrm{n} / 2)+1)] / 2\}$, dengan $\mathrm{n}$ adalah jumlah frekuensi yang terjadi pada tahun yang diinputkan. Sedangkan apabila jumlah data yang akan diobservasi ganjil, maka informasi letak nilai tengah diperoleh dari perhitungan rumus [ $(n+1) / 2]$,dengan $n$ yaitu jumlah frekuensi yang mendapatkan bantuan terjadi pada periode yang diinputkan.

Data yang telah diurutkan berdasarkan frekuensi terkecil sampai terbesar adalah sebagai berikut Nilai tengah tanggungan

$$
\begin{aligned}
1-2 & =\{[(\mathrm{n} / 2)+((\mathrm{n} / 2)+1)] / 2\} \\
& =\{[(4 / 2)+((4 / 2)+1)] / 2\} \\
& =\{[(2+3)] / 2\} \\
& =2,5 \\
3-5 \quad & =\{[(\mathrm{n} / 2)+((\mathrm{n} / 2)+1)] / 2\} \\
& =\{[(6 / 2)+((6 / 2)+1)] / 2\} \\
& =\{[(3+4)] / 2\} \\
& =3,5
\end{aligned}
$$




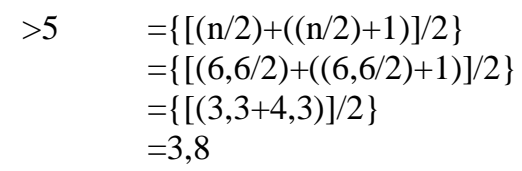

\section{KESIMPULAN}

Adapun kesimpulan yang diperoleh dari penelitian yang dilakukan di SMP Negeri 3 Doloksanggul adalah sebagai berikut:

1. Prosedur penentuan penerimaan bantuan siswa miskin di Doloksanggul adalah dengan memenuhi syarat-syarat penerima bantuan siswa miskin dimana akan di seleksi penerima bantuan siswa miskin setelah itu akan dibuat daftar penerima bantuan siswa miskin dan di serahkan pada dinas pemerintahan.

2. Metode deskripsi diterapkan untuk mendapatkan pola penentuan penerima bantuan siswa miskin sehingga sekolah dapat menentukan siswa miskin lebih mudah.

\section{REFERENCES}

[1] F. A. Hermawati, Data Mining, Yogyakarta: CV.ANDI OFFSET, 2013.

[2] E. t. 1. Kusrini, Algoritma Data Mining, Yogyakarta: CV ANDI OFFSET, 2009.

[3] B. N. d. N. Bahtiar, 2010

[4] F. S. d. D. Juju, "Data Mining".

[5] https://id.wikipedia.org/wiki/Pola. [Online].

[6] Y. Zakariya, "IMPLEMENTASINMETODE NAIVE BAYES DALAM PENENTUAN KELAYAKAN PENERIMA BANTUAN SISWA MISKIN," vol. 01, 2017.

[7] S. A. d. W. Saputro, "IMPLEMENTASI DATA MINING MENGGUNAKAN METODE DESKRIPSI UNTUK MENGETAHUI POLA TRANSAKSI PADA DATA PENJUALAN".

[8] A. P. d. H. Lestiawan, "IMPLEMENTASI DATA MINING MENGGUNAKAN METODE DESKRIPSI UNTUK MENEMUKAN POLA ABSENSI DI BADAN KEPEGAWAIAN DAERAH KOTA SEMARANG," vol. 15, 2016.

[9] M. KH, Secret Fungsi dan Formula pada Excel 2013, Yogyakarta: CV ANDI OFFSET, 2014. 